\title{
FAKTOR - FAKTOR YANG MEMPENGARUHI NILAI PERUSAHAAN DAN RETURN SAHAM
}

\author{
Ryan Ryangga ${ }^{1}$, Yuli Chomsatu $\mathrm{S}^{2}$, Suhendro ${ }^{3}$ \\ 1,2,3 Universitas Islam Batik Surakarta, ryanryangga40300@gmail.com, you.lichoms@gmail.com, \\ dro_s@yahoo.com
}

\begin{abstract}
ABSTRAK
Penelitian ini bertujuan untuk meneliti pengaruh profitabilitas terhadap nilai perusahaan dan return saham, likuiditas terhadap nilai perusahaan dan return saham, dan ukuran perusahaan terhadap nilai perusahaan dan return saham. Penelitian ini menggunakan data dari 4 perusahaan otomotif dan komponen yang terdaftar dalam Bursa Efek Indonesia selama periode 2009 sampai dengan 2018 dengan menggunakan analisis regresi linear berganda. Teknik pengambilan sampel dengan menggunakan metode purposive sampling. Hasil penelitian menunjukkan bahwa profitabilitas dengan proksi ROA dan ukuran perusahaan berpengaruh terhadap nilai perusahaan. Profitabilitas dengan proksi ROA dan ROE berpengaruh terhadap return saham. ROE dan likuiditas tidak berpengaruh terhadap nilai perusahaan. Likuiditas dan ukuran perusahaan tidak berpengaruh terhadap return saham.
\end{abstract}

Kata Kunci: Profitabilitas, Likuiditas, Ukuran Perusahaan, Nilai Perusahaan, Return Saham

\begin{abstract}
This study aims to examine the effect of profitability on firm value and stock returns, liquidity on firm value and stock returns, and firm size on firm value and stock returns. This research uses data from 4 automotive companies. and components listed on the Indonesia Stock Exchange during the period 2009 to 2018 using multiple linear regression analysis. The sampling technique was using purposive sampling method. The results showed that profitability using ROA and firm size has an effect on firm value. Profitability with ROA and ROE proxies has an effect on stock returns. ROE and liquidity have no effect on firm value. Liquidity and firm size have no effect on stock returns..
\end{abstract}

Keywords : Profitability, Liquidity, Company Size, Company Value, Stock Return

Naskah diterima: 03-06-2020, Naskah dipublikasikan: 30-11-2020

\section{PENDAHULUAN}

Nilai perusahaan sangat penting karena nilai perusahaan yang tinggi akan diikuti oleh tingginya kemakmuran pemegang saham. Pada awalnya perusahaan didirikan dengan tujuan untuk memaksimalkan kekayaan pemilik perusahaan atau pemegang saham. Nilai perusahaan dapat mencerminkan nilai aset yang dimiliki perusahaan seperti surat-surat berharga.

Menurut Dewi \& Ekadjaja (2020) perusahaan dapat dinyatakan sebuah entitas ekonomi yang telah didirikan untuk menghasilkan dan memaksimalkan laba perusahaan dan meningkatkan nilai perusahaan setinggi-tingginya dengan menggunakan sumber daya yang dimiliki perusahaan. Dan dari pernyataan diatas dapat ditarik kesimpulan bahwa tujuan jangka pendek dari perusahaan adalah untuk menghasilkan dan memaksimalkan laba perusahaan, sementara untuk tujuan jangka panjang dari perusahaan adalah menyejahterakan pemegang saham dengan cara meningkatkan nilai perusahaan

Menurut Winstone \& Francis (2019) di era revolusi industri 4.0, perusahaan dipaksa untuk dapat bersaing teknologi semakin berkembang. Dan perusahaan harus bisa mencoba membuat yang terbaru inovasi untuk dapat bersaing satu sama lain. Dengan meningkatkan profitabilitas perusahaan dan likuiditas, diyakini juga dapat meningkatkan nilai perusahaan. Jika ada peningkatan, itu berarti perusahaan lebih baik dalam menarik perhatian publik untuk mau berinvestasi di perusahaan. 


\section{JURNAL AKUNTANSI, Vol. 9, No. 2, November (2020)}

Tujuan memaksimumkan kemakmuran pemegang saham dapat ditempuh dengan meningkatkan harga saham untuk semua keuntungan pemegang saham dimasa mendatang. Hal itu menunjukan jika semakin meningkatnya harga saham yang dimiliki suatu perusahaan maka kemakmuran pemegang saham akan meningkat pula (Sartono, 2014)

Berdasarkan data yang dipublikasikan oleh Bursa Efek Indonesia, harga saham perusahaan dipengaruhi oleh keuntungan atau laba pada periode berjalan. Semakin tinggi laba perusahaan, maka semakin banyak investor yang berminat sehingga mempengaruhi harga saham. Kesalahan dalam pengambilan keputusan investasi akan menyebabkan investor mengalami kerugian dan tidak mendapatkan return yang diharapkan. Maka dari itu, investor dapat menjadikan rasio keuangan sebagai bahan pertimbangan dalam berinvestasi untuk menilai kinerja perusahaan (Neni, 2019).

Dengan adanya motivasi untuk mengetahui faktor-faktor dari dalam perusahaan yang mempengaruhi nilai perusahaan dan return saham, serta perbedaan mengenai hasil dari penelitian terdahulu, maka peneliti mengadakan penelitian pada perusahaan yang go public di Indonesia, terutama yang tercatat di BEI. Lebih lanjut penelitian ini difokuskan padaperusahaan otomotif dan komponen yang terdaftar di Bursa Efek Indonesia.

Penelitian ini didasarkan pada perbedaan hasil dari penelitian terdahulu. Menurut Neni (2019), bahwa profitabilitas berpengaruh positif terhadap nilai perusahaan, tetapi di bantah oleh Palupi \& Hendiarto (2018) bahwa pofitabilitas berpengaruh negatif terhadap nilai perusahaan. Sari \& Ariesta (2019) menyatakan bahwa likuiditas berpengaruh positif terhadap nilai perusahaan, tetapi di bantah oleh Permana \& Rahyuda (2019) menyatakan bahwa likuiditas berpengaruh negatif terhadap nilai perusahaan. Menurut Wardhany et al. (2019) menyatakan bahwa ukuran perusahaan berpengaruh positif terhadap nilai perusahaan, tetapi dibantah oleh Oktaviani et al. (2019) bahwa ukuran perusahaan berpengaruh negatif terhadap nilai perusahaan. Menurut Dewi \& Fajri (2019) menemukan bahwa profitabilitas memiliki pengaruh positif dan signifikan terhadap return saham, tetapi dibantah oleh Toar et al. (2020), bahwa profitabilitas berpengaruh negatif dan tidak sinifikan terhadap return saham. Adam \& Afriyenti (2020) menyatakan bahwa likuiditas tidak berpengaruh pada return saham, akan tetapi dibantah oleh Ulimaz (2020), yang menemukan bahwa likuiditas berpengaruh positif terhadap return saham. Menurut Sinaga et al. (2020) menyatakan bahwa ukuran perusahaan berpengaruh positif pada return saham tetapi dibantah oleh Silalahi et al. (2019) menyatakan bahwa ukuran perusahaan berpengaruh negatif dan tidak signifikan terhadap return saham.

Dengan adanya inkonsistensi dari beberapa hasil penelitian terdahulu (maka penulis tertarik untuk melakukan penelitian mengenai faktor - faktor yang mempengaruhi nilai perusahaan dan return saham.

\section{KAJIAN LITERATUR \\ Teori Stakeholder}

Menurut Grey et al, (1997) teori stakeholder merupakan teori yang berkaitan dengan bagaimana cara perusahaan mengelola stakeholdernya. Dalam teori ini keberlangsungan hidup perusahaan dan keberhasilannya tergantung pada hubungan yang optimal antara perusahaan dengan berbagai kelompok stakeholdernya.

Ghozali \& Chariri (2007) juga mengelompokkan stakeholders menjadi dua yaitu stakeholders primer dan stakeholders sekunder. Stakeholders primer merupakan stakeholders yang mempengaruhi dan dipengaruhi secara langsung oleh strategi dari perusahaan. Kelompok ini berisikan shareholder, pemilik, investor, karyawan maupun customer. Sedangkan stakeholders sekunder adalah stakeholders yang mempengaruhi maupun dipengaruhi secara tidak langsung oleh strategi perusahaan seperti pemerintah, masyarakat umum, serta lingkungan.

Stakeholders pada dasarnya memiliki kemampuan untuk mengendalikan atau mempengaruhi pemakaian sumber-sumber ekonomi yang digunakan perusahaan. Kemampuan tersebut dapat berupa kemampuan untuk membatasi pemakaian sumber ekonomi yang terbatas (modal dan tenaga kerja), akses terhadap media yang berpengaruh, kemampuan untuk mengatur perusahaan atau kemampuan untuk mempengaruhi konsumsi atas barang dan jasa yang dihasilkan perusahaan. Oleh karena itu, ketika stakeholder mengendalikan sumber ekonomi yang penting bagi perusahaan, maka perusahaan akan bereaksi dengan cara-cara memuaskan keinginan stakeholder. 


\section{JURNAL AKUNTANSI, Vol. 9, No. 2, November (2020)}

\section{Nilai Perusahaan}

Menurut Sartono (2014), Nilai Perusahaan adalah nilai jual sebuah perusahaan sebagai suatu bisnis yang sedang beroperasi. Adanya kelebihan nilai jual diatas nilai likuidasi adalah nilai dari organisasi manajemen yang menjalankan perusahaan itu.

Nilai Perusahaan dapat diproksikan dengan Price Book Value (PBV). Price to Book Value (PBV) adalah rasio yang menunjukkan apakah harga saham yang diperdagangkan overvalued (diatas) atau undervalued (di bawah) nilai buku saham (Fakhruddin \& Hadianto, 2001)

$$
P B V=\frac{\text { Market Price per Share }}{\text { Book Value per Share }}
$$

Nilai buku per lembar saham dapat dirumuskan sebagai berikut Brigham et al (2009):

$$
\text { Book Value per Share }=\text { Total Ekuitas/Jumlah Saham yang Beredar }
$$

\section{Return Saham}

Menurut Halim (2005), Return Saham disebut juga sebagai pendapatan saham dan merupakan perubahan nilai harga saham periode t dengan t-1. Dan berarti bahwa semakin tinggi perubahan harga saham maka semakin tinggi return saham yang dihasilkan. Return saham dapat diproksikan dengan :

Keterangan :

$$
R_{i t}=\frac{P_{i t}-P_{i t-1}}{P_{i t-1}}
$$

$\mathrm{R}_{\mathrm{it}} \quad=$ Return saham pada periode $\mathrm{t}$

$\mathrm{P}_{\text {it }} \quad$ = Harga saham pada periode $\mathrm{t}$

$\mathrm{P}_{\mathrm{it}-1} \quad=$ Harga saham pada periode $\mathrm{t}-1$

\section{Profitabilitas}

Profitabilitas adalah kemampuan perusahaan untuk menghasilkan laba pada periode tertentu. Untuk mengukur tingkat profitabilitas dalam penelitian ini menggunakan rasio ROA (Return On Assets), ROE (Return On Equity). Berikut merupakan indikator pengukuran untuk ROA :

$$
\text { Return On Asset }(R O A)=\frac{\text { Laba bersih setelah pajak }}{\text { Total Aset }}
$$

Return on Equity (ROE) merupakan rasio profitabilitas untuk menilai kemampuan perusahaan dalam menghasilkan laba dari investasi pemegang saham perusahaan tersebut yang dinyatakan dalam persentase. $R O E$ dihitung dari penghasilan(income) perusahaan terhadap modal yang diinvestasikan oleh para pemilik perusahaan (pemegang saham biasa dan pemegang saham preferen). Berikut merupakan indikator pengukuran :

$$
\text { Return On Equity }(R O E)=\frac{\text { Laba bersih setelah pajak }}{\text { Total Ekuitas }}
$$

\section{Likuiditas}

Rasio likuiditas diukur dengan current ratio, current ratio merupakan rasio yang digunakan untuk mengukur kemampuan perusahaan dalam melunasi hutang jangka pendeknya dengan menggunakan aktiva lancarnya, current ratio dirumuskan sebagai berikut:

$$
\text { Current Ratio }=\frac{\text { Current Asset }}{\text { Current LIabilities }}
$$




\section{JURNAL AKUNTANSI, Vol. 9, No. 2, November (2020)}

\section{Ukuran Perusahaan}

Ukuran perusahaan merupakan suatu skala dimana perusahaan diklasifikasikan menurut besar kecilnya berdasarkan pada Total aktiva suatu perusahaan, semakin besar total aktiva maka semakin besar pula ukuran perusahaan tersebut (Prasetya, 2013). Perusahaan dengan ukuran yang lebih besar memiliki akses yang lebih besar untuk mendapat sumber pendanaan dari berbagai sumber, sehingga dapat memperoleh pinjaman dari pihak luar ataupun kreditur yang akan lebih mudah karena perusahaan dengan ukuran besar memiliki kemungkinan lebih besar dalam hal menarik investor. Ukuran perusahaan dapat dihitung menggunakan rumus:

\section{Ukuran Perusahaan $($ Firm Size $)=\log$ Total Aset}

\section{Pengembangan Hipotesis}

Penelitian yang dilakukan oleh Dewi \& Ekadjaja (2020) menyatakan bahwa profitabilitas berpengaruh positif signifikan terhadap nilai perusahaan. Hasil penelitian yang sama oleh Yanti \& Darmayanti (2019) yang menunjukan bahwa profitabilitas mempunyai pengaruh terhadap nilai perusahaan. Pengaruh profitabilitas terhadap nilai perusahaan juga mendapatkan hasil yang sama dari penelitian Sakdiah (2019). Hipotesis penelitian ini dirumuskan sebagai berikut:

\section{H1 : Profitabilitas berpengaruh terhadap Nilai Perusahaan}

Tingkat likuiditas merupakan kemampuan atau tingkatan perusahaan dalam memenuhi kewajiban jangka pendeknya. Dalam memenuhi jangka pendeknya, manajemen perusahaan harus cermat menggunakan modal yang dimiliki perusahaan dan manajemen perusahaan harus cermat dalam mengelola risiko yang akan timbul pada perusahaan Sari \& Ariesta (2019). Ini sejalan dengan penelitian yang dilakukan oleh Dewi \& Ekadjaja (2020) dan Maharani (2020) yang menyatakan bahwa likuiditas mempengaruhi nilai perusahaan. Hipotesis penelitian ini dirumuskan sebagai berikut:

\section{H2 : Likuiditas berpengaruh terhadap Nilai Perusahaan}

Ukuran perusahaan mengambarkan besar kecilnya suatu perusahaan yang dinyatakan dengan total aktiva. Semakin besar total aktiva maka akan semakin besar ukuran suatu perusahaan, semakin besar juga modal yang akan ditanam. Dengan demikian ukuran dari aset yang dimiliki oleh perusahaan Wardhany et al. (2019). Menurut penelitian Oktaviani et al. (2019) ukuran perusahaan berpengaruh terhadap nilai perusahaan. Sedangkan menurut penelitian Sakdiah (2019) ukuran perusahaan berpengaruh positif signifikan terhadap nilai perusahaan. Hipotesis penelitian ini dirumuskan sebagai berikut:

\section{H3 : Ukuran Perusahaan berpengaruh terhadap Nilai Perusahaan}

Profitabilitas merupakan kemampuan perusahaan untuk menghasilkan laba. Menurut penelitian Fahmi et al. (2019), Dewi \& Sudiartha (2019) bahwa profitabilitas berpengaruh negatif terhadap return saham. Dengan demikian dapat disimpulkan bahwa profitabilitas berpengaruh negative terhadap return saham. Hipotesis penelitian ini dirumuskan sebagai berikut:

\section{H4 : Profitabilitas berpengaruh terhadap Return Saham}

Likuiditas adalah kemampuan perusahaan untuk memenuhi kewajiban finansial dalam jangka pendek dengan dana lancar yang tersedia (Wiagustini, 2010). Menurut penelitian Dewi \& Sudiartha, (2019). Likuiditas berpengaruh positif dan signifikan terhadap return saham. Penelitian tersebut sejalan dengan Dewi \& Fajri (2019) menunjukkan bahwa likuiditas berpengaruh positif dan tidak signifikan terhadap return saham. Hipotesis penelitian ini dirumuskan sebagai berikut:

\section{H5 : Likuiditas berpengaruh terhadap Return Saham}

Ukuran perusahaan adalah ukuran besar atau kecil suatu perusahaan dengan melihat total aset pada laporan keuangan. Menurut penelitian Dewi \& Ratnadi (2019) menunjukkan bahwa ukuran perusahaan tidak berpengaruh terhadap return saham. Sedangkan dalam penelitian Roiyah 


\section{JURNAL AKUNTANSI, Vol. 9, No. 2, November (2020)}

\& Priyadi (2019), Ayem \& Astuti (2019)menunjukkan bahwa ukuran perusahaan berpengaruh terhadap return saham. Hipotesis penelitian ini dirumuskan sebagai berikut:

\section{H6 : Ukuran Perusahaan berpengaruh terhadap Return Saham}

\section{Kerangka Pemikiran}

Berdasarkan telaah pustaka dan hasil penelitian terdahulu, maka model analisis pengaruh faktor-faktor yang mempengaruhi nilai perusahaan dan return saham tersebut dapat digambarkan pada Gambar Kerangka Pemikiran berikut ini :

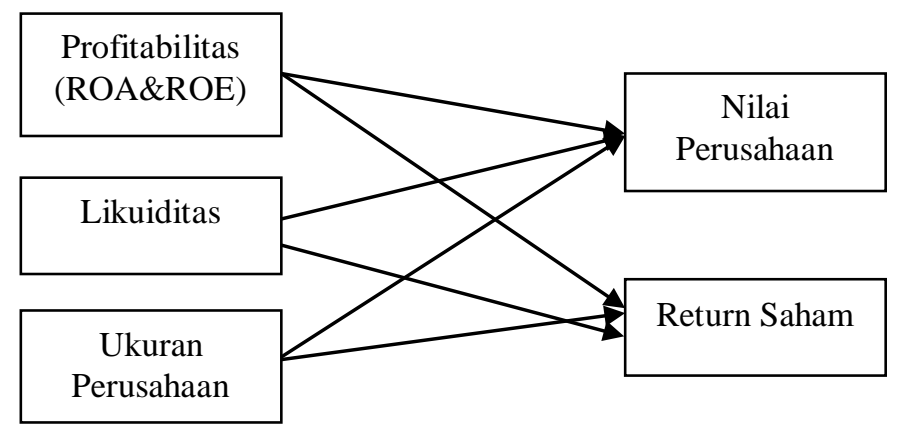

Gambar 1. Kerangka Pikir

\section{METODE PENELITIAN}

Populasi penelitian ini adalah perusahaan otomotif dan komponen di Indonesia yang terdaftar di Bursa Efek Indonesia tahun 2009 - 2018. Metode pengambilan sample yang digunakan dalam penelitian ini adalah metode purposive sampling.

Tabel 1. Kriteria Sampel

\begin{tabular}{|l|c|}
\hline \multicolumn{1}{|c|}{ Deskripsi } & Jumlah Perusahaan \\
\hline $\begin{array}{l}\text { Jumlah perusahaan otomotif dan komponen } \\
\text { yang tercatat di Bursa Efek Indonesia }\end{array}$ & $\mathbf{1 3}$ \\
\hline $\begin{array}{l}\text { Jumlah perusahaan otomotif dan komponen } \\
\text { yang tidak di delisting dari BEI }\end{array}$ & $\mathbf{( 1 )}$ \\
\hline $\begin{array}{l}\text { Jumlah perusahaan otomotif dan komponen } \\
\text { yang IPO pada periode penelitian }\end{array}$ & $\mathbf{( 1 )}$ \\
\hline $\begin{array}{l}\text { Jumlah perusahaan yang mengalami laba } \\
\text { pada periode peneltitian }\end{array}$ & $\mathbf{( 7 )}$ \\
\hline Jumlah sampel perusahaan & $\mathbf{4}$ \\
\hline
\end{tabular}

Sumber : data diolah, 2020

Model dari pesamaan regresi linier berganda dalam penelitian ini adalah:

$$
\begin{aligned}
& \mathrm{Y} 1=\mathrm{a}+\mathrm{b} 1 \mathrm{X} 1+\mathrm{b} 2 \mathrm{X} 2+\mathrm{b} 3 \mathrm{X} 3+\mathrm{b} 4 \mathrm{X} 4+\mathrm{e} \\
& \mathrm{Y} 2=\mathrm{a}+\mathrm{b} 1 \mathrm{X} 1+\mathrm{b} 2 \mathrm{X} 2+\mathrm{b} 3 \mathrm{X} 3+\mathrm{b} 4 \mathrm{X} 4+\mathrm{e}
\end{aligned}
$$

\section{Keterangan:}

$\begin{array}{ll}\text { Y1 } & \text { : Nilai Perusahaan } \\ \text { Y2 } & \text { : Return Saham } \\ \text { a } & \text { : Konstanta } \\ \text { b } & \text { : Koefisien regresi } \\ \text { X1 } & \text { : ROA } \\ \text { X2 } & \text { : ROE } \\ \text { X3 } & \text { : Likuiditas } \\ \text { X4 } & \text { : Ukuran Perusahaan } \\ \text { e } & \text { : Error }\end{array}$




\section{JURNAL AKUNTANSI, Vol. 9, No. 2, November (2020)}

\section{Analisis Data}

Dalam penelitian ini, untuk menganalisis pengaruh pada setiap variabel independen dan dependen maka digunakan analisis regresi linear berganda. Pengujian hipotesis dilakukan dengan program SPSS versi 18, pengujian ini dilakukan antara lain:

1. Analisis Regresi Linier Berganda

Model dari pesamaan regresi linier berganda digunakan untuk menguji hubungan antara satu atau lebih variabel independen dengan satu variabel dependen. Model ini digunakan untuk menguji hubungan apakah terdapat pengaruh yang positif atau negatif antara kedua variabel tersebut.

2. Uji hipotesis (uji-t)

Uji t atau uji parsial adalah uji yang digunakan untuk menguji bagaimana pengaruh masing-masing variabel independen terhadap variabel dependen. Hasil dari uji t dapat dilihat pada tabel coefficient pada kolom significance. Jika probabilitas nilai t atau signifikansi $<0,05$ maka dapat dikatakan bahwa terdapat pengaruh antara variabel independen terhadap variabel dependen. Tetapi jika probabilitas nilai $t$ atau signifikasi $>0,05$, maka dapat dikatakan bahwa tidak terdapat pengaruh yang signifikan antara variabel independen dan variabel dependen.

\section{HASIL DAN PEMBAHASAN Model Regresi}

Tabel 2. Model Regresi Firm Value

\begin{tabular}{cc}
\hline Variabel & B \\
\hline (Constant) & -7.371 \\
ROA & 0.106 \\
ROE & -0.006 \\
LIKUIDITAS & 0.250 \\
SIZE & 0.462 \\
\hline
\end{tabular}

Sumber : Data diolah, 2020

Berdasarkan tabel diatas persamaan analisis linear berganda memberikan pengertian sebagai berikut :

$$
\text { Nilai Perusahaan = -7,371 + 0,106 ROA - 0,006 ROE + 0,250 Likuiditas + 0,462 Size + e }
$$

Nilai perusahaan (konstanta) adalah -7,371 memiliki arti apabila semua variabel independen bernilai atau sama dengan 0, maka nilai perusahaan bernilai sebesar -7,371. ROA memiliki nilai koefisien regresi sebesar 0,106 hal ini menunjukkan bahwa setiap kenaikan ROA 1 satuan maka nilai perusahaan naik sebesar 0,106 dengan asumsi variabel lain tetap. ROE memiliki nilai koefisien regresi sebesar -0,006 hal ini menunjukkan bahwa setiap kenaikan ROE 1 satuan maka nilai perusahaan turun sebesar -0,006 dengan asumsi variabel lain tetap. Likuiditas memiliki nilai koefisien regresi sebesar 0,250 hal ini menunjukkan bahwa setiap kenaikan likuiditas 1 satuan maka nilai perusahaan naik sebesar 0,250 dengan asumsi variabel lain tetap. Ukuran perusahaan (Size) memiliki nilai koefisien regresi sebesar 0,462 hal ini menunjukkan bahwa setiap kenaikan size 1 satuan maka nilai perusahaan naik sebesar 0,462 dengan asumsi variabel lain tetap.

Tabel 3. Model Regresi Return Saham

\begin{tabular}{cc}
\hline Variabel & B \\
\hline (Constant) & 1,233 \\
ROA & $-0,177$ \\
ROE & 0,124 \\
LIKUIDITAS & 0,112 \\
SIZE & $-0,089$ \\
\hline
\end{tabular}

Sumber : Data diolah, 2020 


\section{JURNAL AKUNTANSI, Vol. 9, No. 2, November (2020)}

Berdasarkan tabel diatas persamaan analisis linear berganda memberikan pengertian sebagai berikut :

$$
\text { Return Saham = 1,233 -0,177 ROA + 0,124 ROE + 0,112 Likuiditas - 0,089 Size + e }
$$

Nilai perusahaan (konstanta) adalah 1,233 memiliki arti apabila semua variabel independen bernilai atau sama dengan 0 , maka nilai perusahaan bernilai sebesar 1,233. ROA memiliki nilai koefisien regresi sebesar -0,177halini menunjukkan bahwa setiap kenaikan ROA 1 satuan maka nilai perusahaan turun sebesar $-0,177$ dengan asumsi variabel lain tetap. ROE memiliki nilai koefisien regresi sebesar 0,124 hal ini menunjukkan bahwa setiap kenaikan ROE 1 satuan maka nilai perusahaan naik sebesar 0,124 dengan asumsi variabel lain tetap. Likuiditas memiliki nilai koefisien regresi sebesar 0,112 hal ini menunjukkan bahwa setiap kenaikan likuiditas 1 satuan maka nilai perusahaan naik sebesar 0,112 dengan asumsi variabel lain tetap. Ukuran perusahaan (Size) memiliki nilai koefisien regresi sebesar -0,089 hal ini menunjukkan bahwa setiap kenaikan size 1 satuan maka nilai perusahaan turun sebesar 0,089 dengan asumsi variabel lain tetap.

\section{Uji hipotesis}

Tabel 4. Uji Hipotesis Model Firm Value

\begin{tabular}{crcccc}
\hline Variabel & $\mathbf{T}_{\text {hitung }}$ & $\mathbf{T}_{\text {tabel }}$ & Sig & Prob & Ket \\
\hline ROA & 2,241 & 2,03011 & 0,031 & $<0,05$ & Diterima \\
ROE & $-0,211$ & 2,03011 & 0,834 & $>0,05$ & Ditolak \\
Likuiditas & 1,527 & 2,03011 & 0,136 & $>0,05$ & Ditolak \\
SIZE & 6,015 & 2,03011 & 0,000 & $<0,05$ & Diterima \\
\hline
\end{tabular}

Berdasarkan hasil perhitungan diatas diperoleh nilai t hitung ROA sebesar 2,241. Berdasarkan kriteria pengujian $t$ hitung lebih besar dari t tabel 2,241 > 2,03011 dan nilai signifikan lebih kecil dari 0,05 yaitu 0,031<0,05 maka Ho ditolak dan Ha diterima, maka variabel ROA berpengaruh secara signifikan terhadap Nilai Perusahaan. Hasil pengujian ini sejalan dengan Oktrima (2017) dan Setyani (2018). Hal ini menunjukkan tinggi rendahnya profitabilitas (ROA) mempengaruhi terhadap nilai perusahaan.

Berdasarkan hasil perhitungan diatas diperoleh niai $t$ hitung ROE sebesar -0,211. Berdasarkan kriteria pengujian $\mathrm{t}$ hitung lebih kecil dari t tabel $-0,211<2,03011$ dan nilai signifikan lebih besar dari 0,05 yaitu 0,834 >0,05 maka Ho diterima dan Ha ditolak, maka variabel ROE tidak ada pengaruh secara signifikan terhadap Nilai Perusahaan. Hasil pengujian ini sejalan dengan Dewi \& Tarnia (2011) hal ini dapat diartikan bahwa dalam melakukan investasi tidak hanya melihat tingkat pengembalian yang tinggi melainkan investor juga melihat kondisi lingkungan investasi. Apabila tingkat pengembalian tinggi, tetapi iklim investasi tidak baik, maka investor akan mempertimbangkan suatu investasi.

Berdasarkan hasil perhitungan diatas diperoleh niai t hitung likuiditas sebesar 1,527. Berdasarkan kriteria pengujian thitung lebih kecil dari t tabel 1,527 < 2,03011 dan nilai signifikan lebih besar dari 0,05 yaitu 0,136<0,05 maka Ho diterima dan Ha ditolak, maka variabel likuiditas tidak berpengaruh terhadap Nilai Perusahaan. Hasil pengujian ini sejalan dengan Dewi \& Ekadjaja (2020) dan Maharani (2020). Dalam memenuhi jangka pendeknya, manajemen perusahaan harus cermat menggunakan modal yang dimiliki perusahaan dan manajemen perusahaan harus cermat dalam mengelola risiko yang akan timbul pada perusahaan (Sari \& Ariesta, 2019)

Berdasarkan hasil perhitungan diatas diperoleh nilai t hitung ukuran perusahaan sebesar 6,015. Berdasarkan kriteria pengujian $t$ hitung lebih besar dari $t$ tabel 6,015 > 2,03011 dan nilai signifikan lebih kecil dari 0,05 yaitu 0,000 < 0,05 maka Ho ditolak dan Ha diterima, maka variabel ukuran perusahaan berpengaruh terhadap Nilai Perusahaan. Hasil pengujian ini sejalan dengan Oktaviani et al. (2019) dan Sakdiah (2019). Ukuran perusahaan mengambarkan besar kecilnya suatu perusahaan yang dinyatakan dengan total aktiva. Semakin besar total aktiva maka akan semakin besar ukuran suatu perusahaan, semakin besar juga modal yang akan ditanam. 


\section{JURNAL AKUNTANSI, Vol. 9, No. 2, November (2020)}

Tabel 5. Uji Hipotesis Model Return Saham

\begin{tabular}{crrrrc}
\hline Variabel & $\mathbf{T}_{\text {hitung }}$ & $\mathbf{T}_{\text {tabel }}$ & Sig & Prob & Ket \\
\hline ROA & $-2,577$ & 2,03011 & 0,014 & $<0,05$ & Diterima \\
ROE & 2,914 & 2,03011 & 0,006 & $<0,05$ & Diterima \\
Likuiditas & 0,472 & 2,03011 & 0,640 & $>0,05$ & Ditolak \\
& & & & & \\
SIZE & $-0,794$ & 2,03011 & 0,432 & $>0,05$ & Ditolak \\
\hline
\end{tabular}

Berdasarkan hasil perhitungan diatas diperoleh niai thitung ROA sebesar -2,577. Berdasarkan kriteria pengujian t hitung lebih besar dari t tabel -2,577 > 2,03011 dan nilai signifikan lebih kecil dari 0,05 yaitu 0,014 < 0,05 maka Ho ditolak dan Ha diterima, maka variabel ROA berpengaruh secara signifikan terhadap Return Saham. Hasil pengujian ini sejalan dengan Susilowati \& Turyanto (2011). Hasil penelitian ini mengindikasikan bahwa para investor tidak semata - mata menggunakan ROA sebagai ukuran dalam menilai kinerja perusahaan untuk memprediksi total return saham di pasar modal (terutama di BEI)

Berdasarkan hasil perhitungan diatas diperoleh niai $t$ hitung ROE sebesar 2,914. Berdasarkan kriteria pengujian thitung lebih besar dari t tabel 2,914 > 2,03011 dan nilai signifikan lebih kecil dari 0,05 yaitu 0,006 < 0,05 maka Ho ditolak dan Ha diterima, maka variabel ROE berpengaruh secara signifikan terhadap Return Saham. Hasil pengujian ini sejalan dengan Tumonggor et al. (2017) Perusahaan yang masih berukuran kecil memiliki nilai ROE yang cenderung meningkat dengan cepat sejalan dengan peningkatan laba bersih (earning). Hal itu menyebabkan regresi linier dengan sample perusahaan yang mempunyai fase pertumbuhan yang berbeda memberikan hasil yang signifikan.

Berdasarkan hasil perhitungan diatas diperoleh niai t hitung likuiditas sebesar 0,472. Berdasarkan kriteria pengujian t hitung lebih kecil dari t tabel 0,472 $<2,03011$ dan nilai signifikan lebih besar dari 0,05 yaitu 0,640>0,05 maka Ho diterima dan Ha ditolak, maka variabel likuiditas tidak berpengaruh signifikan terhadap Return Saham. Hasil pengujian ini sejalan dengan Dewi \& Fajri (2019) dan Dewi \& Sudiartha (2019). Likuiditas (Current Ratio) digunakan untuk mengetahui kemampuan perusahaan memenuhi kewajiban jangka pendeknya. Jika perusahaan dalam operasionalnya memperoleh laba yang optimal maka akan semakin lancar pendanaan dan pembiayaan perusahaan, dan sebaliknya. Likuiditas yang rendah menunjukkan risiko likuiditas yang tinggi, sedangkan likuiditas yang tinggi menunjukkan adanya kelebihan aktiva lancar yang akan memiliki pengaruh kurang baik terhadap profitabilitas perusahaan.

Berdasarkan hasil perhitungan diatas diperoleh niai $\mathrm{t}$ hitung ukuran perusahaan sebesar 0,794. Berdasarkan kriteria pengujian thitung lebih kecil dari t tabel 0,794 < 2,02269 dan nilai signifikan lebih besar dari 0,05 yaitu 0,432>0,05 maka Ho diterima dan Ha ditolak, maka variabel ukuran perusahaan tidak berpengaruh signifikan terhadap Return Saham. Hasil pengujian ini sejalan dengan Roiyah \& Priyadi (2019) dan Ayem \& Astuti (2019). Semakin besar ukuran suatu perusahaan maka tidak diragukan lagi perusahaan tersebut unggul dalam segi kekayaan dan kinerja sehingga akan memberikan daya tarik kepada investor untuk percaya serta ingin menanamkan modalnya. Beberapa peneliti percaya bahwa perusahaan besar karena berbagai aktivitas dan jumlah kredit yang mereka miliki di pasar modal global serta menyediakan dananya dengan bunga yang lebih rendah sehingga dapat memiliki profitabilitas dan return yang lebih tinggi

\section{PENUTUP \\ Simpulan}

Berdasarkan hasil penelitian dan analisis diatas maka dapat diambil kesimpulan bahwa Profitabilitas dengan menggunakan proksi ROA berpengaruh terhadap nilai perusahaan. Ada beberapa faktor yang menyebabkan nilai ROA berpengaruh antara lain salah satunya dengan adanya peningkatan kinerja perusahaan. Dengan kinerja perusahaan yang meningkat akan mengakibatkan kemampuan perusahaan meraih laba juga meningkat. Sedangkan profitabilitas dengan 


\section{JURNAL AKUNTANSI, Vol. 9, No. 2, November (2020)}

menggunakan proksi ROE tidak berpengaruh terhadap nilai perusahaan. Dalam hal ini ada beberapa perusahaan otomotif yang mengalami kerugian setiap tahunnya sehingga mempengaruhi nilai ROE karena laba menurun tetapi nilai ekuitas tetap besar sehingga mempengaruhi nilai ROE.

Likuiditas tidak berpengaruh terhadap nilai perusahaan diterima. Nilai Likuiditas yang rendah dapat menimbulkan resiko biaya modal yang rendah apabila dana-dana di perusahaan dapat digunakan dengan baik, sehingga investor akan melihat itu sebagai sinyal positif. Ukuran perusahaan tidak berpengaruh terhadap nilai perusahaan. Perusahaan yang meningkatkan nilai ukuran perusahaannya maka harga saham menjadi naik dan nilai perusahaan pun akan menjadi tinggi.

Profitabilitas dengan menggunakan proksi ROE berpengaruh terhadap return saham. Dengan menggunakan proksi ROA juga menghasilkan nilai ROA berpengaruh terhadap return saham. Perusahaan yang mengalami laba akan meningkatkan nilai saham sehingga akan meningkatkan nilai return saham tersebut. Sehingga rasio yang digunakan untuk melihat kinerja perusahaan untuk menghasilkan laba menjadi naik..

Likuiditas tidak berpengaruh terhadap return saham. Hal ini dikarenakan perusahaan tidak dapat mengoptimalkan kemampuan perusahaan dalam membayar kewajiban jangka pendeknya. Ukuran perusahaan tidak berpengaruh terhadap return saham. Hal ini menunjukkan bahwa nilai ukuran perusahaan yang kecil akan tidak memberikan daya tarik terhadap investor untuk menanamkan modalnya pada perusahaan.

\section{Saran}

Untuk penelitian selanjutnya lebih baik menggunakan perusahaan sub sektor lainnya yang terdaftar di Bursa Efek Indonesia dengan menambah variabel bebas dan variabel terikat serta menambah periode dan sampel penelitian. Keterbatasan penulis dalam penelitian ini adalah menggunakan sampel dan variabel yang sedikit.

\section{REFERENSI}

Adam, A. P., \& Afriyenti, M. (2020). Pengaruh rasio likuiditas, solvabilitas dan rentabilitas terhadap return saham pada perusahaan LQ45 yang terdaftar di BEI. Jurnal Eksplorasi Akuntansi Vol.2 No.1.

Dewi, A. S., \& Fajri, I. (2019). Pengaruh Likuiditas dan Profitabilitas Terhadap Return Saham Pada Perusahaan Manufaktur Yang Terdaftar di Bursa Efek Indonesia . Jurnal Pundi, Vol. 03, No. 02.

Dewi, I. A., \& Ratnadi, N. M. (2019). Pengaruh Inflasi, Profitabilitas dan Ukuran Perusahaan Pada Return Saham Perusahaan Terindeks LQ45. E-Jurnal Akuntansi Universitas Udayana Vol.27.

Dewi, N. L., \& Sudiartha, I. G. (2019). Pengaruh Profitabilitas, Likuiditas, Leverage dan Ukuran Perusahaan Terhadap Return Saham Pada Perusahaan Food And Beverage. E-Jurnal Manajemen Vol.6 No.2.

Dewi, R. R., \& Tarnia, T. (2011). Pengaruh Kinerja Keuangan Terhadap Nilai Perusahaan Dengan Good Corporate Governance Sebagai Variabel Moderasi. Jurnal Informasi, Perpajakan, Akuntansi Dan Keuangan Publik, 115-132.

Dewi, V. S., \& Ekadjaja, A. (2020). Pengaruh Profitabilitas, Likuiditas Dan Ukuran Perusahaan Terhadap Nilai Perusahaan Pada Persahaan Manufaktur. Jurnal Multiparadigma Akuntansi Tarumanagara Vol.2 No.1.

Fahmi, Kosasih, \& Putra, R. A. (2019). Pengaruh Profitablitas Dan Leverage Terhadap Return Saham Pada Perusahaan Bumn Yang Terdaftar Di Indeks LQ45. Jurnal Ilmiah Mahasiswa Ekonomi Manajemen Vol. 4 No.3.

Ghozali, I., \& Chariri, A. (2007). Teori Akuntansi. Semarang: Badan Penerbit Universitas Diponegoro.

Grey, \& et.al. (1997). Manajemen Proyek. LPFE Universitas Indonesia.

Halim, A. (2005). Analisis Investasi. Jakarta: Salemba Empat. 
JMaharani, S. (2020). The Influence Of Profitability, Dividend Policy, And Liquidity Toward Firm Value On Manufactring Comanies Registered In Indonesia Stock Exchange In 2014-2018 Period.

Neni, M. B. (2019). Pengaruh Profitabilitas, Likuiditas, Dan Leverage Terhadap Return Saham Perusahaan Manufaktur Di BEI. Jurnal Akuntansi Keuangan dan Bisnis Vol. 12, No. 2, 67-76.

Oktaviani, M., Rosmaniar, A., \& Hadi, S. (2019). Pengaruh Ukura Perusahaan (Size) Dan Struktur Modal Terhadap Nilai Perusahaan. Balance Vol. XVI No. 1.

Oktrima, B. (2017). Pengaruh Profitabilitas, Likuiditas Dan Struktur Modal Terhadap Nilai Perusahaan. Jurnal Sekuritas Vol.1 No.1.

Palupi, R. S., \& Hendiarto, S. (2018). Kebijakan Hutang, Profitabilitas dan Kebijakan Dividen Pada Nilai Perusahaan Properti \& Real Estate. Jurnal Ecodemica, Vol. 2 No. 2.

Roiyah, M., \& Priyadi, M. P. (2019). Pengaruh Profitabilitas, Ukuran Perusahaan Dan Corporate Governance. Jurnal Ilmu dan Riset Akuntansi.

Sakdiah. (2019). Pengaruh Profitabilitas, Leverage, Ukuran Perusahaan Dan Likuiditas Terhadap Kebijakan Deviden Dan Nilai Perusahaan. Jurnal Jurusan Tadris IPS Society Vol.10 No.2.

Sari, R. L., \& Ariesta, M. (2019). Pengaruh Profitabilitas Dan Tingkat Likuiditas Terhadap Nilai Persahaan Dengan Kebijakan Deviden Sebagai Variabel Intervening.

Sartono, A. (2014). Manajemen Keuangan, Teori dan Aplikasi, Edisi Empat. Yogyakarta: BPFE.

Sinaga, A. N., Eric, Rudy, \& Wiltan, V. (2020). Current Ratio, Debt to Equity Ratio, Return On Equity, Devided Payout Ratio Dan Size Terhadap Return Saham Perusahaan Trade, Service \& Investment. Journal of Economic, Business and Accounting Vol.3 No.2. 